\title{
A regurgitalite of the Middle Triassic (Muschelkalk) from Upper Silesia (Poland)
}

\author{
Robert Niedźwiedzki ${ }^{1}$, Dawid Surmik ${ }^{2}$, Agnieszka Chećko, \\ Mariusz A. Salamon ${ }^{4}$ \\ ${ }^{1}$ Wrocław University, Institute of Geological Sciences; pl. M. Borna 9, 50-204 Wrocław, Poland; \\ ORCID ID:0000-0002-6222-3977 \\ ${ }^{2}$ University of Silesia in Katowice, Faculty of Natural Sciences, Institute of Earth Sciences; ul. Będzinska 60, 41-200 Sosnowiec, \\ Poland; e-mail: dawid@surmik.pl (corresponding author); ORCID ID: 0000-0003-0121-9592 \\ ${ }^{3}$ University of Silesia in Katowice, Faculty of Natural Sciences, Institute of Earth Sciences, ul. Będzinska 60, 41-200 Sosnowiec, \\ Poland; GEOsfera Ecological Education Center, Town Hall of Jaworzno, ul. św. Wojciecha 100, 43-600 Jaworzno, Poland; \\ ORCID ID: 0000-0001-5225-1408 \\ ${ }^{4}$ University of Silesia in Katowice, Faculty of Natural Sciences, Institute of Earth Sciences; ul. Będzinska 60, 41-200 Sosnowiec, \\ Poland; ORCID ID: 0000-0001-9399-2798
}

(C) 2021 Authors. This is an open access publication, which can be used, distributed and reproduced in any medium according to the Creative Commons CC-BY 4.0 License requiring that the original work has been properly cited.

Received: 9 February 2021; accepted: 30 March 2021; first published online: 28 April 2021

Abstract: A bromalite from the Middle Triassic (Muschelkalk) of southern Poland, Sadowa Góra Quarry, is herein described and interpreted as a regurgitalite. The fossils occurring within the regurgitalite are angular and have sharp edges. They are represented by common fragments of thin-shelled bivalves as well as rare crinoid and gastropod remains. The composition of the collected inclusion is different from that of the host rock. There are many candidates that could have produced the regurgitalite, including durophagous sharks, marine reptiles, the actinopterygian Colobodus, or nautiloids. Our finding adds to the emerging evidence of durophagous predation in the Triassic sea of Polish part of the Germanic Basin. It is the second record of a regurgitalite from the Muschelkalk of Upper Silesia.

Keywords: bromalites, regurgitalites, Middle Triassic, Muschelkalk, Upper Silesia, Poland.

\section{INTRODUCTION}

Coprolites, or fossil excrement, represent the most commonly described type of fossilized products of digestion (so-called bromalites). Other, somewhat less common types of bromalites include: (i) cololites, which represent fossilized non-valvular intestinal contents, (ii) enterospirae, which represent fossilized content preserved in the valvular intensine, (iii) gastrolites, which represent fossilized stomach contents, and (iv) regurgitalites, which represent fossilized orally ejected waste (for definitions see Hunt 1992, Northwood 2005, Salamon et al. 2012 and literature cited therein).
The criteria for identifying bromalites and distinguishing them from one another are well discussed in the literature (e.g., Williams 1972, Hunt 1992, Northwood 2005, Hunt et al. 2012a, 2012b, Salamon et al. 2012, 2014, Brachaniec et al. 2015, Zatoń et al. 2015, Niedźwiedzki et al. 2016a, 2016b, Qvarnström et al. 2017, Gordon et al. 2020).

Bromalites that are mainly composed of crushed shell fragments can be problematic to distinguish from accumulations of shell debris produced by abiotic (hydrodynamic, abrasion-induced and compaction related) processes (e.g., Oji et al. 2003, Zatoń et al. 2007a, 2007b, Zatoń \& Salamon 2008, Salamon et al. 2012, 2014, Hoffmann et al. 2020). 
Recently, however, Salamon et al. $(2018,2020)$ underlined that certain features of shell fragmentation can be useful in recognizing crushing predation in the fossil record.

In this paper we report the second regurgitalite (compare Salamon et al. 2012) from the Muschelkalk of Upper Silesia which indicates the occurrence of durophagous predation in Triassic in the Polish sector of the Germanic Basin. This is also the first such finding from the Sadowa Góra locality during nine years of fieldworks in the quarry.

\section{GEOLOGICAL FRAMEWORK}

The Sadowa Góra Quarry is situated in the northern part of Jaworzno, southern Poland (coordinates $50^{\circ} 13^{\prime} 43.7^{\prime \prime} \mathrm{N} 19^{\circ} 16^{\prime} 35.8^{\prime \prime}$ E; Fig. 1A, B). The quarry reveals deposits of the Middle Triassic (the lowermost Muschelkalk) represented by the Lower Gogolin Beds and the lower part of the Upper Gogolin Beds. The lowest part of Muschelkalk consists of limestone, which is informally divided into the Entolium and Dadocrinus units, and represented by marly shales, organodetrital and crinoidal limestones, fine crystalline limestones and dolomitic limestones with numerous Dadocrinus-type crinoid faunas, the bivalve Entolium discites and rare non-spiral coprolites. Above, sediments of the 1st Wellenkalk Unit are exposed. These are wavy pelitic and marly limestones intercalated by crinoidal limestones with bivalve detritus, marls, nodular limestones and by marly limestones with numerous bivalves of the genus Plagiostoma. In the sediments of the 1st Wellenkalk Unit in the northern part of the quarry, numerous ichnofossils (Rhizocorallium isp.), ophiuroids (Aspiduriella sp., A. similis, Arenorbis sp.; Surmik et al. 2020) and cephalopods (Beneckeia sp. and nautiloids) were documented. The examined bromalite was also found within the 1st Wellenkalk Unit in the western part of the Sadowa Góra Quarry, in a light brown crinoidal limestone layer with a maximum thickness of $25 \mathrm{~cm}$. In this bromalite-bearing layer, numerous columnals and pluricolumnals of Dadocrinus sp., detritus of bivalves, rare echinoid spines, indeterminate gastropods, Plagiostoma striatum bivalves, reptile bones, shark teeth (Acrodus and Hybodus) and actinopterygian scales, were observed. The Cellular Limestone Unit which is located above is devoid of fauna and represented by yellow dolomitic limestones and calcareous dolomites. The sediments of the next unit, the Conglomeratic Horizon, are built of fine-crystalline, organodetritic limestones, intraclastic limestones and marls with bivalves, gastropods, echinoderms and the remains of vertebrates (for a very detailed description of the Sadowa Góra Quarry section see Surmik et al. 2020). Chronostratigraphically, the lowermost part of the limestone with Entolium and Dadocrinus units is dated to the latest Olenekian, and the younger parts of the Lower Gogolin Beds are dated as Aegean (Nawrocki \& Szulc 2000).
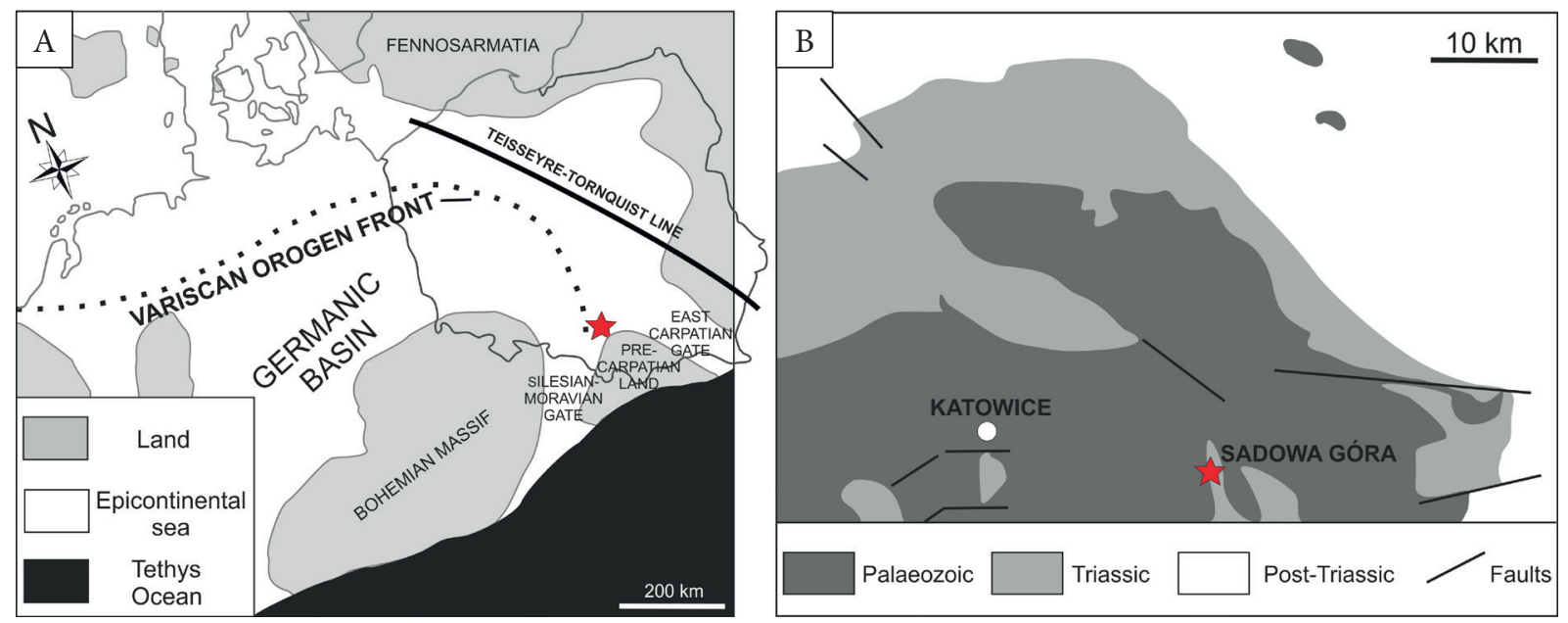

Fig. 1. Paleogeographic map of Central Europe during Middle Triassic. The Sadowa Góra Quarry is marked with a red star (A). Detailed map of Upper Silesia with the Sadowa Góra Quarry marked with a red star (B). Slightly modified after Zatoń et al. (2008) and Surmik et al. (2020) 


\section{PALEOENVIRONMENTAL FRAMEWORK}

In the Middle Triassic, the Upper Silesia region was located within the southeastern part of the Germanic Basin (Fig. 1A). During the period of the deposition of the Lower Gogolin Beds (Aegean) this basin was connected with Tethys mainly by the East-Carpathian Gate, located to the east of the research area (Niedźwiedzki \& Salamon 2002). However, the exchange of fauna with Tethys was very limited as inferred from the high degree of endemism of the Silesian macrofauna (74\%) for the Lower Gogolin Beds (Salamon \& Niedźwiedzki 2005).

The Lower Gogolin Beds originated in the area of a shallow-marine carbonate ramp. The limestone with Entolium and Dadocrinus units, with numerous proximal tempestites, represents coastal shoals of the inner ramp zone and was formed during the transgressive system tract in well-oxygenated waters. The 1st Wellenkalk Unit represents the slightly deeper and calmer waters of the middle ramp and was formed during the highstand system tract. The layers of crinoidal limestones within this unit are interpreted as distal tempestites. There was normal salinity during the sedimentation of both units. The Cellular Limestone Unit represents a short episode of shallowing, including an emersion phase and a period of strong increase in salinity (Szulc 2000, Niedźwiedzki 2005, Szulc \& Becker 2007).

\section{MATERIALS AND METHODS}

The sample was carefully cleaned in hot water and subsequently heated in water with perhydrol (a $30 \%$ aqueous solution of hydrogen peroxide) up to $100^{\circ} \mathrm{C}$.

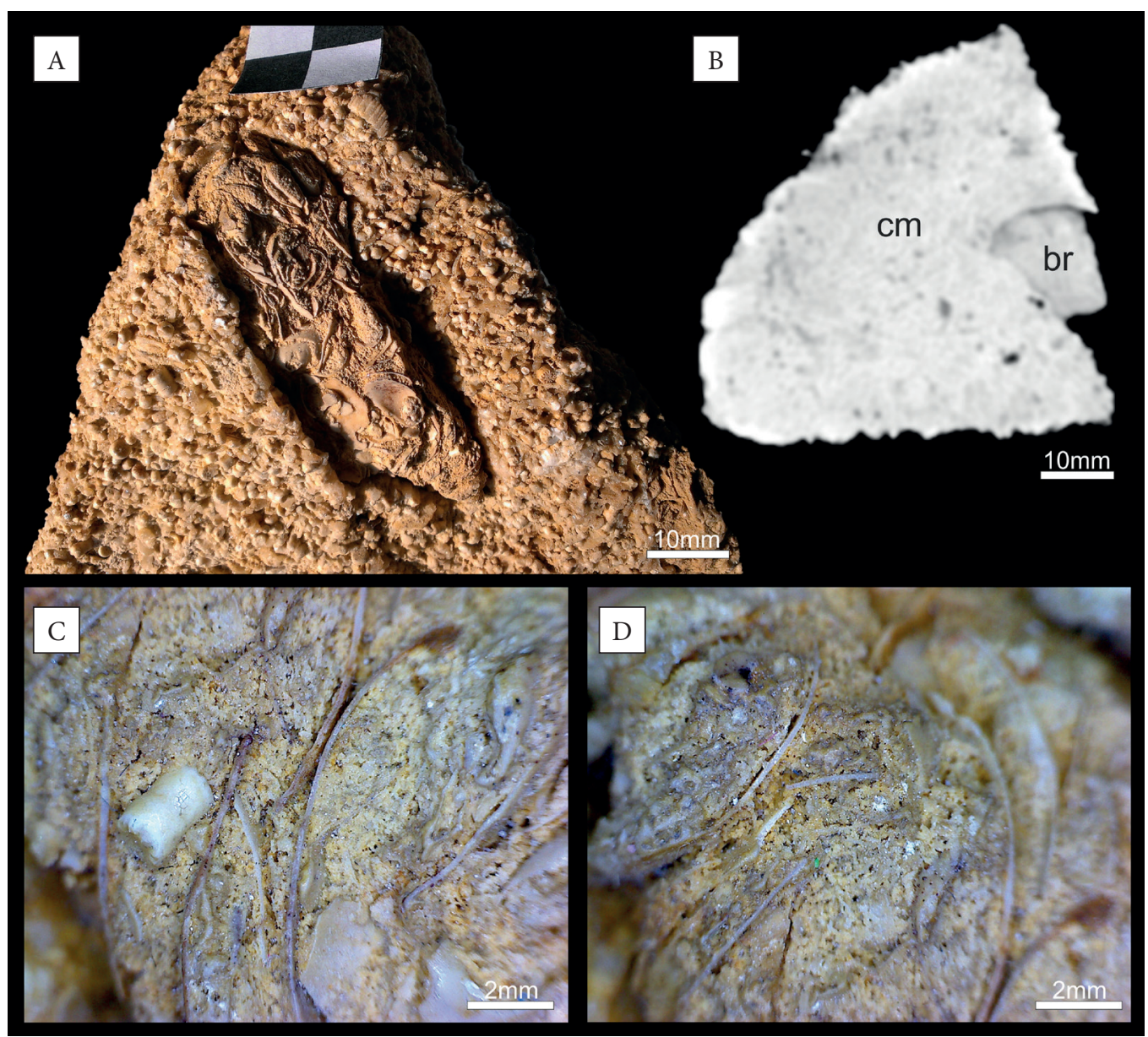

Fig. 2. Photograph of bromalite on the surface of the crinoid limestone block (A). CT virtual section of the specimen (acronyme number OEEG/m-007) exhibiting homogenous crinoid matrix with easily distinguishable bromalite. cm - crinoid matrix, br-bromalite (B). Enlargement of the bromalite surface (crinoid columnal and sharp-edged fragments of bivalves) $(C, D)$ 
The virtual sections of the specimen were obtained by using a GE Healthcare Discovery CT750 HD 64-channel computed X-ray tomographic unit at the Department of Diagnostic Imaging of Regional Hospital of Trauma Surgery, Piekary Śląskie, Poland. The tomographic (CT) scans were recorded as DICOM files and processed using the ImageJ/Fuji software (Schindelin et al. 2012). The CT equipment was applied to investigate the internal structure of the crinoid-rich limestone block where the bromalite is embedded.

Fauna from the bromalite illustrated in the figures were photographed using a SONY RX10 digital camera.

The investigated bromalite is housed in the University of Silesia in Katowice, Faculty of Natural Sciences, Poland, and registered under the catalogue number: OEEG/m-007 (Fig. 2).

\section{RESULTS}

The bromalite (Fig. 2) is elongate and has a length of $6.5 \mathrm{~cm}$ and a maximum width of $2.4 \mathrm{~cm}$. Its upper edge is rounded and the lower one is cone-shaped with a rounded apex. Most fossils occurring within the bromalite are angular, sharp-edged and are represented by fragments of thin-shelled bivalves (probably Entolium discites; $98 \%$ visible on the bromalite surface). Other fossils at the surface of the structure include crinoid remains belonging to $D a$ docrinus [one columnal and one brachial plate (1\%) and an incomplete shell of a small gastropod (1\%)]. The surrounding sediment consists of a mass accumulation of crinoid columnals, pluricolumnals and brachials of Dadocrinus (97\%), very rare shell fragments of the bivalve Plagiostoma (2\%) and actinopterygian fish scales: 1\% (Fig. 2, 3). Fossils in the bromalite have no signs of abrasion or bioerosion in contrast to the fossils present in surrounding sediment (almost half of the crinoid remains and 70\% of bivalve detritus possess these traces). In the case of two small fragments of shells visible in the lower part of the bromalite, their sharp-edged edges are observed. No epibionts were found on the fossil remains within the bromalite or in the surrounding sediment.
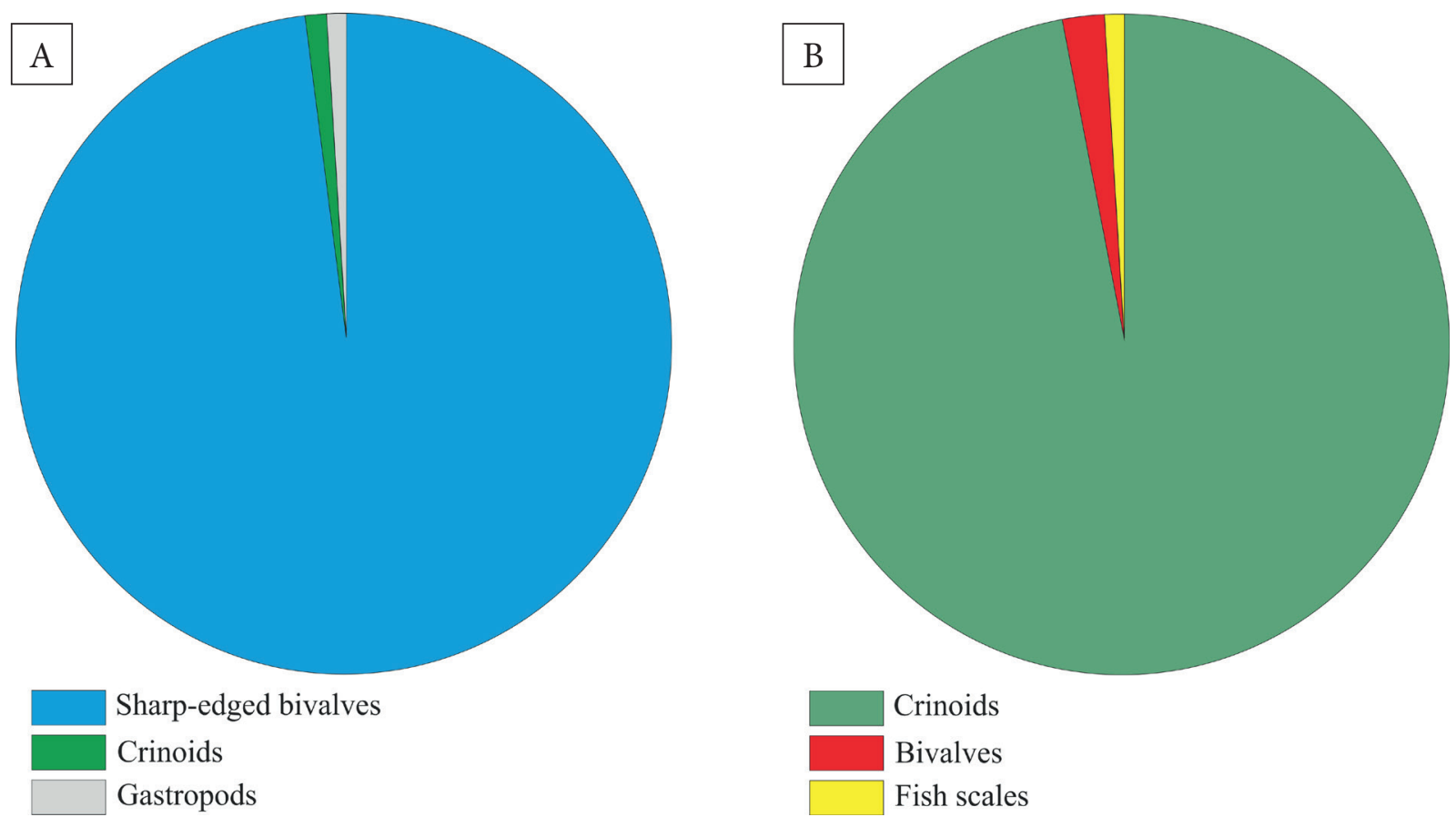

Fig. 3. Comparison of the composition of the regurgitalite (A) vs. surrounding rock (B) 


\section{DISCUSSION}

The studied structure clearly stands out morphologically from the surrounding sediment (Fig. 2). It shows a completely different faunal composition: it is composed almost exclusively of thin-shelled bivalve detritus, while the surrounding rock is made of crinoid ossicles with very rare shell detritus that is mainly thick-shelled. Another difference is the degree of abrasion or bioerosion, which is notable in crinoidal limestone and very minor in the studied structure.

These observations show that the distinct accumulation illustrated herein is genetically different from the rock in which it is embedded. The tomographic images show that the investigated structure does not continue deep into the rock (Fig. 2B, online supplementary material - Movie-01), which suggests that it is not a deep burrow. Moreover, in the Lower Gogolin Beds, ichnofossil canals of sizes close to the diameter of the studied structure belong only to Rhizocorallium or Teichichnus ichnogenus. The first taxon commonly occurs within carbonate muds and typically has a filling identical to the surrounding rock, and the second taxon has subvertical canals filled with fecal pellets (Szulc 2000). Additionally, in the crinoidal layer with the studied accumulation, no ichnofossils were recorded and there are also no intraclasts. Directly above this crinoidal layer there are no organodetrical layers, so the structure in question cannot be a load cast. The characteristics of the studied structure, especially its different composition of fossil fragments which consist of angular shell fragments that are randomly grouped, indicate that it is a bromalite and not an abiotic accumulation of the bioclasts. The low degree of roundness of the shell edges, minor signs of dissolution, absence of groundmass, elongated shape and relatively small thickness indicate altogether that the specimen is a regurgitalite and not a coprolite or a gastric residue (fossilized stomach contents; i.e., consumlite) (compare Hasiotis et al. 2007, Salamon et al. 2014, 2020, Gordon et al. 2020, Hoffmann et al. 2020).

\section{POSSIBLE PRODUCERS}

Fossils of five predatory groups (of which some representatives may have been durophagous) are known from the Lower Gogolin Beds of the Upper Silesia region (see Wysogórski 1903-1908, Assmann
1937, 1944, Liszkowski 1993, Chrząstek \& Niedźwiedzki 1998, Brachaniec et al. 2015, Surmik 2016, Antczak et al. 2020, this paper). These include decapods, cephalopods (nautiloids and ammonoids), sharks, actinopterigian fishes and marine reptiles.

Although some Triassic decapods may have fed on shelled fauna (bivalves or gastropods, see Klompmaker et al. 2011), common ichnofossils of the Gogolin Beds linked to decapods (Rhizocorallium or Teichichnus) appears to be too small to have been made by the same animal that produced a regurgitalite measuring $6.5 \mathrm{~cm}$ in length (for more details see Knaust 2013, Stachacz \& Matysik 2020). The Silesian decapod Pemphix silesiacus had a cephalothorax of about $3 \mathrm{~cm}$ in length (the largest Triassic representatives of the genus reached a height of over $6 \mathrm{~cm}$ length of cephalothorax; see Schmidt 1928) and the diameter of Rhizocorallium burrows in Gogolin Beds reach up to a maximum of $3.5 \mathrm{~cm}$ (own observations). Furthermore, the walls and filling of the canals of these ichnogenera in Lower Gogolin Beds never contain shell detritus. The largest representatives of the ammonoids to have been found in the age equivalent of the Lower Gogolin Beds in the German part of the Germanic Basin (e.g. Beneckeia) had shells of less than 15 $\mathrm{cm}$ in diameter (Schmidt 1928). Moreover, according to Hoffmann et al. (2020), there is no absolute certainty that extinct ammonoids could have produced regurgitates. Nautiloids from the Lower Gogolin Beds of Upper Silesia were often much larger than Beneckeia, with shell diameters of up to $30 \mathrm{~cm}$ (Klug \& Lehmkuhl 2004). Specimens of nautiloids were found in the 1st Wellenkalk of the Sadowa Góra Quarry (Niedźwiedzki et al. 2021). The body chamber length of the Triassic Germanonautilus is about 150 to $190^{\circ}$ (Klug \& Lehmkuhl 2004) (about of half the length of the last whorl), which means that the body of the animal exceeded $30 \mathrm{~cm}$ and the largest specimens of this genus could theoretically be the producer of studied regurgitalite. However, nautiloids are extremely rare in the Lower Gogolin Beds of Upper Silesia (compare Assmann 1937, Schmidt 1938, Senkowiczowa \& Kotański 1979). Moreover, according to Hoffmann et al. (2020) modern coleoids have very strong alkaline gastric fluids that require regurgitation to get rid of carbonaceous material. If fossil nautiloids digested similarly, there should be no abundant limestone 
biodetrites in their non-regurgitalites without any signs of dissolution, and such biodetrites prevail in the studied bromalite.

In the sea in the Upper Silesia area during the deposition of the Lower Gogolin Beds, there were many taxa of durophagous fish, such as sharks: Acrodus (3 species), Lissodus (2 species), Palaeobates angustus and actinopterygians: Colobodus (3 species), Cenchrodus (2 species), Nephrotus chorzowiensis. Teeth, scales and fragments of jaws of durophagous actinopterygians are often found in the rocks of the Lower Gogolin Beds, and a single more complete skeletal fragments of Colobodus have also been found (Wysogórski 1903-1908, Schmidt 1928, Assmann 1944, Liszkowski 1993, Chrząstek \& Niedźwiedzki 1998, Brachaniec et al. 2015, Surmik 2016, Antczak et al. 2020). Acrodus teeth were found in Sadowa Góra Quarry during the current investigations. Moreover, several large (up to about $5 \mathrm{~cm}$ ) tooth plates of dipnoan Ceratodus were found in the Roetian and Lower Gogolin Beds in Upper Silesia (Schmidt 1928; pers. obs.). There are also numerous remains of marine reptiles (mainly nothosaurids) in the Lower Gogolin Beds (Chrząstek \& Niedźwiedzki 1998, Surmik 2010, Surmik et al. 2014, Antczak et al. 2020), however fossil durophagous reptiles are extremely rare and represented by several fragments of jaws of Hemilopas (Assmann 1944, Surmik 2016), Placodus sp. and Cyamodus (Wysogórski 19031908). In the Sadowa Góra Quarry no remains of the durophagous reptiles were found. The sauropterygians from this location are only represented by piscivorous forms, especially by middle-sized nothosarus (Surmik et al. 2014), determined here as Nothosaurus cf. marchicus, known from the numerous findings in Germanic Basin. Also, two isolated cervical vertebrae of the archosauromorph Protanystropheus cf. antiquus were documented in recent years (pers. obs.).

Mesozoic dipnoans were restricted to freshwater environments and their remains found in coastal marine deposits are interpreted as allochtonous (Skrzycki et al. 2018). Among other durophagous vertebrate predators, many of them appear to be too small to be a producer of a $6.5 \mathrm{~cm}$ regurgitalite. This applies to the shark Lissodus (15 to $50 \mathrm{~cm}$ in length; see Fischer 2008) and most actinopterygians. Colobudus was among the largest
Triassic actinopterygians. Two species of this genus reached about $60 \mathrm{~cm}, C$. maximus reached up to $47 \mathrm{~cm}$ length (see Schmidt 1938), a few others were above $30 \mathrm{~cm}$, but most of representatives of this genus are late Anisian or Ladinian species (Schmidt 1928, Cartanyà et al. 2015). From large species of Colobodus, only C. maximus appeared in the Germanic Basin during the early Anisian (e.g., Schmidt 1938, Oosterink \& Poppe 1979), also in Lower Gogolin Beds (Brachaniec et al. 2015). Large durophagous sharks were Acrodus (the reconstructed body length of Middle Triassic specimens from Switzerland about 1.8-2.5 m (Mutter 1998) and Palaeobates (maximally $1 \mathrm{~m}$ in length; see Romano \& Brinkmann 2010), both classified within Hybodontiformes. Comparing reptile tooth row length between Simosaurus (body length $4 \mathrm{~m}$ ) and Hemilopas (Surmik 2016 and literature cited therein), it can be estimated that Hemilopas would have been less than $1.5 \mathrm{~m}$ in length. A similar size may have been reached by early Anisian placodonts (Klein \& Scheyer 2014). To sum up, the most likely producer of the studied regurgitalite were hybodontid sharks (Acrodus or Palaeobates), whereas direct evidence of durophagy in hybodonts have been documented from the Late Mesozoic (Vullo 2011, Lane \& Maisey 2012). Actinoptergian fish Colobodus maximus, nautiloids, and durophagous marine reptiles cannot be ruled out either, although this is much less likely due to their small size and/or rarity in the study area.

\section{CONCLUSIONS}

An accumulation of fragmented bivalve shells detritus found in crinoidal limestone layer within the 1st Wellenkalk Unit (Lower Gogolin Beds, Aegean) in the Sadowa Góra Quarry in Upper Silesia is interpreted as a regurgitalite produced by a durophagous marine predator.

During the Aegean, there were many durophagous marine predators in the sea of the Upper Silesia region (decapods, cephalopods, sharks, actinopterygian fishes, reptiles). However, considering the relatively large size of the regurgitalite and the abundance of fossils of different groups of durophagous predators in Lower Anisian of Upper Silesia, the most likely producer of the studied bromalite were the sharks Acrodus or Palaeobates. 
We thank Dr. Wojciech Wawrzynek, M.D., the head of the Department of Diagnostic Imaging of Regional Hospital of Trauma Surgery (Piekary Ślaskie, Poland) for providing the CT unit for our research. Spencer G. Lucas and Martin Qvarnström are acknowledged for their many valuable suggestions in the early draft of this manuscript. Two journal referees are acknowledged for some valuable remarks that helped to improve the present manuscript. Part of the work was supported financially by the Institute of Geological Sciences, University of Wrocław (subvention no. $501 \mathrm{KD} 76$ ) and NCN grant no. 2019/32/C/NZ4/00150 for DS.

\section{REFERENCES}

Antczak M., Ruciński M.R., Stachacz M., Matysik M. \& Król J.J., 2020. Diversity of vertebrate remains from the Lower Gogolin Beds (Anisian) of southern Poland. Annales Societatis Geologorum Poloniae, 90, 419-433.

Assmann P., 1937. Revision der Fauna der Wirbellosen der oberschlesischen Trias. Abhandlungen der Königlich Preussischen Geologischen Landesanstalt, N. F., 170, Preussischen Geologischen Landesanstalt, Berlin.

Assmann P., 1944. Die Stratigraphie der oberschlesischen Trias. Teil 2: Der Muschelkalk. Abhandlungen des Reichsamts für Bodenforschung, 208, Reichsamt für Bodenforschung, Berlin.

Brachaniec T., Niedźwiedzki R., Surmik D., Krzykawski T., Szopa K., Gorzelak P. \& Salamon M.A., 2015. Coprolites of marine vertebrate predators from the Lower Triassic of southern Poland. Palaeogeography, Palaeoclimatology, Palaeoecology, 435, 118-126.

Cartanyà J., Fortuny J., Bole A. \& Mutter R., 2015. Colobodus giganteus (Beltan, 1972) comb. nov. from the Upper Muschelkalk Facies of Catalonia (NE Iberian Peninsula). Neues Jahrbuch für Geologie und Paläontologie, Abhandlungen, 278, 323-333.

Chrząstek A. \& Niedźwiedzki R., 1998. Kręgowce retu i dolnego wapienia muszlowego na Śląsku. Acta Universitatis Wratislaviensis. Prace Geologiczno-Mineralogiczne, 64, 69-81.

Fischer J., 2008. Brief synopsis of the hybodont form taxon Lissodus Brough, 1935, with remarks on the environment and associated fauna. Paläontologie, Stratigraphie, Fazies, Freiberger Forschungshefte, C 528, 1-23.

Gordon C.M., Roach B.T., Parker W.G. \& Briggs D.E.G., 2020. Distinguishing regurgitalites and coprolites: A case study using a Triassic bromalite with soft tissue of the pseudosuchian archosaur Revueltosaurus. Palaios, 35, 111-121.

Hasiotis S.T., Platt B.F., Hembree D.I. \& Everhart M.J., 2007. The trace-fossil record of vertebrates. [in:] Miller W. (ed.), Trace Fossils: Concepts, Problems, Prospects, Elsevier, 196-218.

Hoffmann R., Stevens K., Keupp H., Simonsen S. \& Schweigert G., 2020. Regurgitalites - a window into the trophic ecology of fossil cephalopods. Journal of the Geological Society, 177, 82-102.

Hunt A.P., 1992. Late Pennsylvanian coprolites from the Kinney Brick Quarry, central New Mexico with notes on the classification and utility of coprolites. New Mexico Museum of Natural History and Science, 138, 221-229.
Hunt A.P., Lucas S.G., Spielmann J.A., Cantrell A., Suazo T. \& Lerner A.J., 2012a. Bromalites from the Tinajas lagerstätte (Late Pennsylvanian: Late Missourian), central New Mexico, USA. New Mexico Museum of Natural History and Science, 57, 175-183.

Hunt A.P., Santucci V.L., Tweet J.S. \& Lucas S.G., 2012b. Vertebrate coprolites and other bromalites in national park service areas. New Mexico Museum of Natural History and Science, 57, 343-353.

Klein N. \& Scheyer T.M., 2014. A new placodont sauropterygian from the Middle Triassic of the Netherlands. Acta Palaeontologica Polonica, 59, 887-902.

Klompmaker A.A. \& Fraaije R.H.B., 2011. The oldest (Middle Triassic, Anisian) lobsters from the Netherlands: taxonomy, taphonomy, paleoenvironment, and paleoecology. Palaeontologia Electronica, 14, 1A. http:// palaeo-electronica.org/2011_1/220/index.html.

Klug C. \& Lehmkuhl A., 2004. Soft-tissue attachment structures and taphonomy of the Middle Triassic nautiloid Germanonautilus. Acta Palaeontologica Polonica, 49, 243-258.

Knaust D., 2013. The ichnogenus Rhizocorallium: Classification, trace makers, palaeoenvironments and evolution. Earth Science Reviews, 126, 1-47.

Lane J.A \& Maisey J.G., 2012. The visceral skeleton and jaw suspension in the durophagous hybodontid shark Tribodus limae from the Lower Cretaceous of Brazil. Journal of Paleontology, 86, 886-905.

Liszkowski J., 1993. Die Selachierfauna des Muschelkalks in Polen: Zusammensetzung, Stratigraphie und Paläoökologie. [in:] Hagdorn H. \& Seilacher A. (eds.), Muschelkalk. Schöntaler Symposium 1991, Goldschneck-Verlag, Stuttgart, 177-185.

Mutter R.J., 1998. Tooth variability and reconstruction of dentition in Acrodus sp. (Chondrichthyes, Selachii, Hybodontoidea) from the Grenzbitumenzone (Middle Triassic) of Monte San Giorgio (Ticino, Switzerland). Geologisch-Paläontologische Mitteilungen Innsbruck, 3, 25-31.

Nawrocki J. \& Szulc J., 2000. The Middle Triassic magnetostratigraphy from the Peri-Tethys basin in Poland. Earth and Planetary Science Letters, 182, 77-92.

Niedźwiedzki G., Bajdek P., Owocki K. \& Kear B.P., 2016a. An Early Triassic polar predator ecosystem revealed by vertebrate coprolites from the Bulgo Sandstone (Sydney Basin) of southeastern Australia. Palaeogeography, $\mathrm{Pa}$ laeoclimatology, Palaeoecology, 464, 5-15.

Niedźwiedzki G., Bajdek P., Qvarnström M., Sulej T., Sennikov A.G. \& Golubev V.K., 2016b. Reduction of vertebrate coprolite diversity associated with the end-Permian extinction event in Vyazniki region, European Russia. Palaeogeography, Palaeoclimatology, Palaeoeco$\log y, 450,77-90$.

Niedźwiedzki R., 2005. Stratygrafia, zapis paleontologiczny i warunki sedymentacji wapienia muszlowego na Górny Śląsku. [in:] Jureczka J., Buła Z. \& Żaba J. (red.), Geologia i zagadnienia ochrony środowiska $w$ regionie górnośląskim: LXXVI Zjazd Naukowy Polskiego Towarzystwa Geologicznego, Rudy k/Rybnika, 14-16 września 2005 r.: materiały konferencyjne, Państwowy Instytut Geologiczny, Warszawa, 161-165.

Niedźwiedzki R. \& Salamon M.A., 2002. Migration routes of the Tethyan fauna in the eastern part of the epicontinental Germanic Basin (Poland). Freiberger Forschungshefte, Paläontologie, Stratigraphie, Fazies, 10, 1-8. 
Niedźwiedzki R., Surmik D., Chećko A., Paszcza K., Jain S. \& Salamon M.A., 2021. Oldest nautiloid record from the Triassic Germanic Basin and the first ammonite record from the Aegean (Middle Triassic) of Poland. Palaeogeography, Palaeoclimatology, Palaeoecology [in press].

Northwood C., 2005. Early Triassic coprolites from Australia and their palaeobiological significance. Palaeontology, 48, 49-68.

Oji T., Ogaya C. \& Sato T., 2003. Increase of shell crushing predation recorded in fossil shell fragmentation. Paleobiology, 29, 520-526.

Oosterink H.W. \& Poppe W., 1979. Vissen en visresten uit de Onder-Muschelkalk van Winterswijk. Grondboor en Hamer, 33, 95-112.

Qvarnström M., Niedźwiedzki G., Tafforeau P., Žigaitė Ž. \& Ahlberg P.E., 2017. Synchrotron phase-contrast microtomography of coprolites generates novel palaeobiological data. Scientific Reports, 7, 2723.

Romano C. \& Brinkmann W., 2010. A new specimen of the hybodont shark Palaeobates polaris with three-dimensionally preserved Meckel's cartilage from the Smithian (Early Triassic) of Spitsbergen. Journal of Vertebrate Paleontology, 30, 1673-1683.

Salamon M.A. \& Niedźwiedzki R., 2005. An explanation for low endemism of Triassic crinoids from the epicontinental Germanic Basin, Poland. Geological Quarterly, 49, 331-338.

Salamon M.A., Niedźwiedzki R., Gorzelak P., Lach R. \& Surmik D., 2012. Bromalites from the Middle Triassic of Poland and the rise of the Mesozoic Marine Revolution. Palaeogeography, Palaeoclimatology, Palaeoecology, 321-322, 142-150.

Salamon M.A., Gorzelak P., Niedźwiedzki R., Trzęsiok D. \& Baumiller T.K., 2014. Trends in shell fragmentation as evidence of mid-Paleozoic changes in marine predation. Paleobiology, 40, 14-23.

Salamon M.A., Leśko K. \& Gorzelak P., 2018. Experimental tumbling of Dreissena polymorpha: implications for recognizing durophagous predation in the fossil record. Facies, 64, 10.

Salamon M.A., Brachaniec T. \& Gorzelak P., 2020. Durophagous fish predation traces versus tumbling-induced shell damage - a paleobiological perspective. Palaios, 35, 37-47.

Schindelin J., Arganda-Carreras I., Frise E. et al. 2012. Fiji: an open-source platform for biological-image analysis. Nature Methods, 9, 676-682.

Schmidt M., 1928. Die Lebewelt unserer Trias. Ferdinand Rau, Öhringen.

Schmidt M., 1938. Die Lebewelt unserer Trias. Ferdinand Rau, Öhringen.

Senkowiczowa H. \& Kotański Z., 1979. Gromada Cephalopoda Cuvier, 1797. [in:] Malinowska L. (red.), Budowa geologiczna Polski. T. 3, Atlas skamieniałości przewodnich i charakterystycznych. Cz. 2a, Mezozoik: Trias, Wydawnictwa Geologiczne, Warszawa, 94-103.

Skrzycki P., Niedźwiedzki G. \& Tałanda M., 2018. Dipnoan remains from the Lower-Middle Triassic of the Holy Cross Mountains and northeastern Poland, with remarks on dipnoan palaeobiogeography. Palaeogeography, Palaeoclimatology, Palaeoecology, 496, 332-345.

Stachacz M. \& Matysik M., 2020. Early Middle Triassic (Anisian) trace fossils, ichnofabrics, and substrate types from the southeastern Germanic Basin (Wellenkalk facies) of
Upper Silesia, southern Poland: Implications for biotic recovery following the Permian/Triassic mass extinction. Global and Planetary Change, 194, 103290.

Surmik D., 2010. Preliminary taphonomical analysis of Lower Muschelkalk bone accumulation in Silesia (Poland). [in:] Nowakowski D. (ed.), Fossil vertebrates - morphology systematics evolution: paleontological conference, DN Dariusz Nowakowski, Instytut Biologii, Uniwersytet Przyrodniczy, Wrocław, 110-117.

Surmik D., 2016. Hemilopas mentzeli, an enigmatic marine reptile from the Middle Triassic of Poland revisited. Neues Jahrbuch für Geologie und Paläontologie, Abhandlungen, 282, 209-223.

Surmik D., Skreczko S. \& Wolny M., 2014. The results of palaeontological excavations in the Sadowa Góra quarry (2012-14). Contemporary Trends in Geoscience, 3, 91-100.

Surmik D., Salamon M.A., Chećko A. \& Kędroń K., 2020. Ophiuroids from the Middle Triassic (Muschelkalk) of Sadowa Góra, Jaworzno (southern Poland). Geology, Geophysics \& Environment, 46, 175-182.

Szulc J., 2000. Middle Triassic evolution of the northern Peri-Tethys area as influenced by early opening of the Tethys Ocean. Annales Societatis Geologorum Poloniae, $70,1-48$.

Szulc J. \& Becker A. (eds.), 2007. International Workshop on the the Triassic of Southern Poland: Pan-European correlation of the epicontinental Triassic, 4th meeting September 3-8, 2007: fieldtrip guide. Polish Geological Society, Polish Geological Institute, Institute of Geological Sciences, Jagiellonian University, Cracow, Warsaw.

Vullo R., 2011. Direct evidence of hybodont shark predation on Late Jurassic ammonites. Naturwissenschaften, 98, 545-549.

Williams M.E., 1972. The origin of "spiral coprolites". University of Kansas Paleontological Contribution, 59, 1-19.

Wysogórski J., 1903-1908. Die Trias in Oberschlesien. [in:] Frech F. (red.), Lethaea geognostica: Handbuch der Erdgeschichte mit Abbildungen der für die Formationen bezeichnendsten Versteinerungen. II. Teil: Das Mesozoicum. 1. Band: Trias, Schweizerbart, Stuttgart, 54-64.

Zatoń M., Salamon M.A., Marynowski L. \& Zatoń R., 2007a. Gniazdowe akumulacje szczątków fauny w środkowojurajskich iłach rudonośnych Wyżyny Krakowsko-Wieluńskiej - wnioski paleobiologiczne. Przegląd Geologicz$n y, 55,424-429$.

Zatoń M., Villier L. \& Salamon M.A., 2007b. Signs of predation in the Middle Jurassic of south-central Poland: evidence from echinoderm taphonomy. Lethaia, 40, 139-151.

Zatoń M., Salamon M.A., Boczarowski A. \& Sitek S., 2008. Taphonomy of dense ophiuroid accumulations from the Middle Triassic of Poland. Lethaia, 41, 47-58.

Zatoń M., Niedźwiedzki G., Marynowski L., Benzerara K., Pott Ch., Cosmidis J., Krzykawski T. \& Filipiak P., 2015. Coprolites of Late Triassic carnivorous vertebrates from Poland: an integrative approach. Palaeogeography, Palaeoclimatology, Palaeoecology, 430, 21-46.

Supplementary data associated with this article can be found, in the online version, at: https://doi.org/10.7494/geol.2021.47.1.33.

Movie-01.avi. Video file showing the crinoid-rich limestone block with bromalite rotated along its shorter axis, not to scale. 